Avaiable online at www.babglajol.info

Bangladesh J. Sci. Ind. Res. 43(2), 273-276, 2008

Short Comuunication
BANGLADESH JOURNAL OF SCIENTIFIC AND INDUSTRIAL RESEARCH

E-mail: bjsir07gmail.com

\title{
Microbial Contamination of Water in Around Dhaka City
}

\author{
Sahana Parveen*, M. Shakir Uddin Ahmed and Tania Nasreen \\ Food Microbiology Section, Institute of Food Science and Technology, Bangladesh \\ Council of Scientific and Industrial Research, Dhaka, Bangladesh.
}

\begin{abstract}
A total of 109 water samples were collected from around Dhaka city and examined for microbial contamination. Samples were collected in sterilized screw capped glass bottles, transported to the laboratory in cold and processed within 6 hours of their collection. All river water, pond water and household water were found heavily contaminated with coliform, faecal coliform, E. Coli and Salmonella whereas tube well water and bottled water was devoid of faecal coliform, E. Coli and Salmonella. A significant correlation between total number of total coliform and percentage of Salmonella was also investigated. It is suggested that water must be boiled before use.
\end{abstract}

Key Words: Water contamination, Total coliform, Faecal coliform, Salmonella

\section{Introduction}

Safe drinking water and adequate environmental sanitation are preconditions for health and for success in the fight against poverty, hunger and child deaths. Worldwide in 1995, contaminated water and food caused more than 3 million deaths, of which more than $80 \%$ were among children under age five (WHO 1996). Globally, the World Health Organization (WHO) estimates that 1.8 million people die each year from diarrhoeal diseases. Faechem (1980) reported that at least one and a half thousand million people worldwide used polluted water. This problem is more acute in developing countries where higher incidence of water-borne diseases are reported. In India, more than $70 \%$ of the epidemic emergencies are either water borne or are water related (Khera, et al 1996). Among waterborne diseases of bacterial origin typhoid, bacillary dysentery and diarrhoea are common in Bangladesh. Although a substantial amount of work has been carried out on common water borne pathogens in Bangladesh, unfortunately a little information is available. For this a study was conducted to estimate the quality of var-

* Corresponding author 
ious sources of water and the prevalence of waterborne pathogens.

\section{Materials and Methods}

\section{Sample collection}

A total of 109 water samples were collected from the entire region of the city of Dhaka. Samples of river water (18), Pond water (18), Household Water (45), Tubewell water (19), Bottled water (9) were collected. Samples were collected in sterilized screw capped glass bottles, transported to the laboratory in cold and processed within 6 hours of their collection.

\section{Methodology}

All of the water samples were analyzed by standard methodologies recommended by the American Public Health Association (APHA 1995). To assess the microbial load, indicator parameters, viz. heterotrophic plate count (HPC), Total fungus count (TFC), Total
Coliform count (TCC), Faecal Coliform count (FCC), Salmonella and E. Coli were studied. HPC was enumerated on plate count agar (PCA) by standard plate count, TFC were on potato dextrose agar (PDA) by spread plate technique; TCC, FCC and E. Coli were determined by the most probable number (MPN) method. Isolation of Salmonella was carried out on enrichment method. For Salmonella, $100 \mathrm{ml}$ of water sample was enriched 24 hours at $37^{\circ} \mathrm{C}$ in $100 \mathrm{ml}$ of double strength lactose broth, then 1 loopful of 24 hours culture was transferred to $10 \mathrm{ml}$ selenite broth and incubated 24 hours at $37^{\circ} \mathrm{C}$ in an incubator. One loopfull overnight culture from selenite broth was streaked on bismuth sulphite agar (BSA) and incubated 24 hours at $37^{\circ} \mathrm{C}$. From each sample three typical colonies were biochemically confirmed.

\section{Results and Discussion}

Table I summerized the water samples with source , type and microbial parameters. In

Table I. Microbial contamination of different type of water in Dhaka.

\begin{tabular}{|c|c|c|c|c|c|c|c|}
\hline \multirow[t]{2}{*}{ Water samples } & \multicolumn{5}{|c|}{ Counts (geometric mean) } & \multirow[b]{2}{*}{$\begin{array}{l}\text { E.Coli(cou } \\
\mathrm{nts} / 100 \mathrm{ml})\end{array}$} & \multirow[b]{2}{*}{$\begin{array}{c}\text { Salmonella } \\
(\%)\end{array}$} \\
\hline & $\mathrm{N}$ & $\begin{array}{c}\text { HPC(counts } \\
/ \mathrm{ml})\end{array}$ & $\begin{array}{c}\text { TFC(counts/ } \\
\text { ml) }\end{array}$ & $\begin{array}{c}\text { TCC }(\text { counts } \\
/ 100 \mathrm{ml})\end{array}$ & $\begin{array}{l}\text { FCC(counts } \\
\quad / 100 \mathrm{ml})\end{array}$ & & \\
\hline River water & 18 & $1.12 \times 10^{5}$ & $4.93 \times 10^{2}$ & $2.4 \times 10^{4}$ & $2.4 \times 10^{4}$ & $3.49 \times 10^{2}$ & 100 \\
\hline Pond water & 18 & $4.43 \times 10^{5}$ & $3.02 \times 10^{3}$ & $2.4 \times 10^{4}$ & $2.4 \times 10^{4}$ & $2.12 \times 10^{2}$ & 100 \\
\hline Household water & 45 & $2.30 \times 10^{5}$ & $9.3 \times 10^{1}$ & $1.70 \times 10^{2}$ & $1.70 \times 10^{2}$ & $1.40 \times 10^{2}$ & 84.37 \\
\hline Tubewell water & 19 & $1.8 \times 10^{2}$ & $0.1 \times 10^{1}$ & $1.0 \times 10^{1}$ & N.F & N.F & N.F \\
\hline Mineral water & 09 & $3.50 \times 10^{2}$ & $1.93 \times 10^{3}$ & N.F & N.F & N.F & N.F \\
\hline
\end{tabular}

$\mathrm{N}=$ Number, HPC = Heterotrophic plate count, $\mathrm{TFC}=$ Total fungus count, $\mathrm{TCC}=$ Total coliform count, FCC=Faecal Coliform count, 
comparison to tubewell water and bottled water, river water, pond water and household water showed more pathogenic contamination. All river water, pond water and household water were heavily contaminated with Coliform, Faecal coliform, E. Coli and Salmonella whereas tubewell water and bottled water were devoid of Faecal Coliform, E. Coli and Salmonella. There was no remarkable difference in pathogenic organism among river water, pond water and household water. Geldreich (1994) reported that the rate of salmonella isolation is related to faecal coliforms. Our findings was also similar with that result. From this study we had found that there was a correlation between total coliform and the presence of Salmonella species. Among the different sources of water the correlation was significant in case of river water, pond water and household water (Fig. 1). The presence of coliform, Faecal coliform, E. Coli and Salmonella in a majority of these samples showed that contamination was widespread. However, except for some samples, most drinking water samples were found to be devoid of any pathogenic organism. It is contended that contamination is mainly due to disposal of waste in river and pond, unhygienic conditions related to washing in utensils and bathing. Household water may be contaminated with connecting the supplied pipe line with sewerage system. The Dhaka city is also over crowded which seem to the cause of contamination.

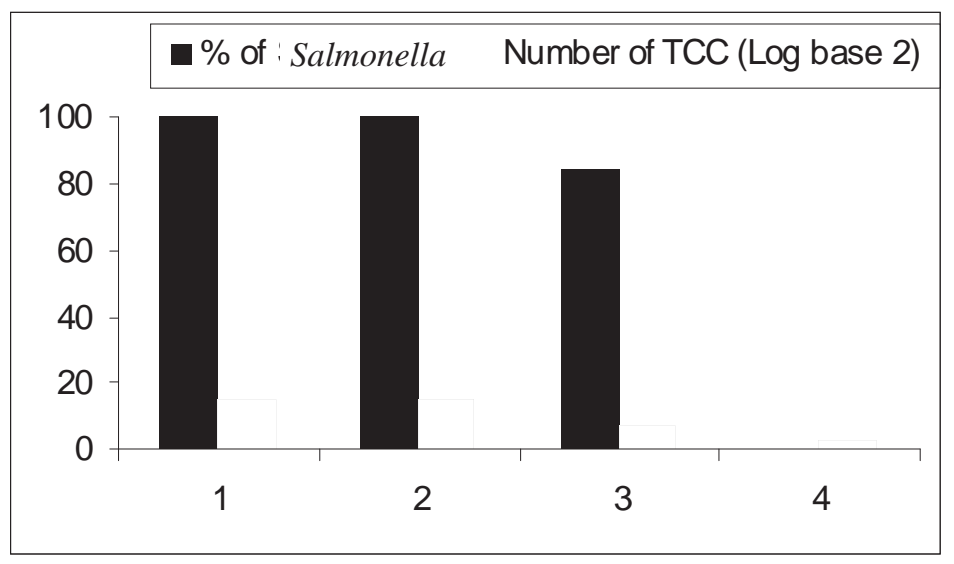

1. River water

2. Pond water

3. Household water

4. Tube well water

Fig. 1: Relationship between TCC and \% of Salmonella. 


\section{Conclusion}

The data presented here may serve as a baseline to which all future data may be compared. Studies in this respect are also warranted to safeguard ourselves against waterborne pathogens and suggested to boil the water before use.

\section{Acknowledgement}

Financial support from Institute of Food Science and Technology, Bangladesh Council of Scientific and Industrial Research, Dhaka is gratefully acknowledged.

\section{References}

American Public Health Association (APHA) (1995) Standard methods for examination of water and wastewater. 19th edition. American Public Health Association, Washington, D.C.USA.

Faechem, R.G. (1980) Bacterial standards for drinking water quality in developing countries. Lancet. 2:255-56.
Geldreich, E.E. (1998) The bacteriology of water. In: Colier, L., Balows, A.and Sussman, M. (Eds.), Microbiology and microbial Infections. 9th ed. Arnold publication, London.

Khera, A.K. Jain, D.C. Dutta, K.K. (1996) Microbial contamination of various water sources in Delhi. J. Commun. Dis. 28:12938.

WHO (1996) The World Health Report. Fighting Diseases, Fostering development. Geneva. Available at: http://www.who.int/whr/ 1996/en/.

WHO (1997) Guidelines for drinking water quality. Vol 3: Surveillance and control of community supplies. The World Health Organisation, Geneva. Available at: http://www.who.int/water_sanitation_healt h/dwq/gdwq3rev/en/.

Received : August 29, 2007;

Accepted : January 17, 2008 